УДК 005.3:37.091[373.2+373.3](477)

https://doi.org/10.33989/2075-146x.2020.26.227418

\title{
СВІТЛАНА БЕРЕЦЬКА
}

ORCID: 0000-0003-1257-1110

Донецький національний університет імені Василя Стуса (м. Вінниця, Україна)

\section{МОДЕЛЬ УПРАВЛІННЯ НАСТУПНІСТЮ ДОШКІЛЬНОЇ ТА ПОЧАТКОВОЇ ШКІЛЬНОЇ ОСВІТИ}

Стаття присвячена обгрунтуванню моделі управління наступності дошкільної та початкової шкільної освіти. Модель управління наступністю дошкільної та початкової шкільної освіти розглянуто як інструмент конструювання майбутніх ситуацій, знаходження альтернатив у розвитку закладу освіти та забезпеченні його конкурентоспроможності. Зміст моделі з'ясовується через концептуальний, нормативний, технологічний та результативний рівні які взаємообумовлені та взаємопов'язані. Підкреслено, що у процесі моделювання та безпосередньої побудови моделі були використані такі принципи: багатовекторність впливу на систему, системно-структурний аналіз, рівневий підхід, послідовність та логічність основних етапів пошуку, конкретність, доцільність обраних методів, цілісність і завершеність процесів. Зауважено, що зберігаючи наступність, заклад дошкільної освіти і школа мають провадити освітню діяльність спільно і системно - всім педагогічним колективом. Наголошено, що лише об'єднавши зусилля педколективів закладів дошкільної і початкової ланок шкільної освіти, а також отримавши підтримку батьківської громади можливо забезпечити психологічно виважений і успішний для дитини перехід з попереднього рівня освіти на наступний.

Ключові слова: наступність, управління, модель, неперервність, дошкільна освіта, початкова шкільна освіта

Постановка проблеми. Одним із пріоритетів Міністерства освіти і науки України залишається переорієнтування системи освіти на потреби людини. Усі громадяни мають уміти вчитися протягом життя і мати доступ до якісної системи освіти - на це мають бути спрямовані зусилля фахівців та чиновників у галузі освіти. Послідовне здобуття освіти можливе за дотримання принципів перспективності й наступності між суміжними ланками освіти - зокрема між дошкільною та початковою.

Аналіз останніх досліджень і публікацій. Питання наступності, її аспекти на різних щаблях освітньої системи

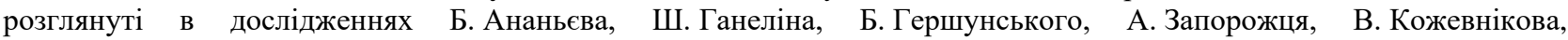
А. Люблінської, А. Мороза, А. Сманцера.

Мета статті - обгрунтувати модель управління наступності дошкільної та початкової шкільної освіти.

Виклад основного матеріалу дослідження. Під моделлю розуміється система, що відбиває певне явище або об’єкт так, що це подає нову інформацію про нього. Модель-образ, у тому числі умовний або уявний (зображення, опис, креслення, графік, план, карта тощо), або прообраз якого - або об'єкта або системи об'єктів («оригіналу» даної моделі), використовуваний у певних умовах у якості «заступника» або «представника» (Кожевников, 2007, с. 24).

Через створення моделі управлінської діяльності здійснюється аналітичний опис системи управління, пояснюються причини іiї недостатньої ефективності, відбувається прогнозування нових умов системи управління, а також наслідків ії впровадження, визначається еталон для порівняння чинної та попередньої систем управління, змістовно обгрунтовується проект реальної системи управління.

У процесі моделювання та безпосередньої побудови моделі були використані такі принципи: багатовекторність впливу на систему, системно-структурний аналіз, рівневий підхід, послідовність та логічність основних етапів пошуку, конкретність, доцільність обраних методів, цілісність і завершеність процесів.

Зміст моделі полягає у перетворенні керівником закладу загальної середньої освіти нових набутих знань у конкретні управлінські вміння. Запропонована модель не лише визначає необхідну керівнику закладу освіти сукупність знань, умінь і навичок, а й залишає можливості для її подальшої розбудови. Представлена нами на рисунку 1 модель управління наступністю дошкільної та початкової шкільної освіти має умовні чотири рівні.

Рівні моделі визначають ступінь величини та значущості іiі складових, необхідних для реалізації управління наступністю дошкільної та початкової шкільної освіти та повноцінної взаємодії керівника 3 учасниками освітнього процесу.

Модель управління наступністю дошкільної та початкової шкільної освіти розглянуто як інструмент конструювання майбутніх ситуацій, знаходження альтернатив у розвитку закладу освіти та забезпеченні його конкурентоспроможності. Зміст моделі з'ясовується через концептуальний, нормативний, технологічний та результативний рівні. Визначені рівні взаємообумовлені та взаємопов'язані. Логіка та послідовність їх змісту взаємообгрунтовані й дотичні одна до одної.

Першим у структурі моделі є концептуальний рівень. У перекладі з лат. «концепція» - це система поглядів, певне розуміння явищ, процесів або єдиний, визначальний замисел, головна думка будь-якого твору, наукової праці»; система доказів конкретного положення, система поглядів на те чи інше явище, світогляд, світорозуміння, погляди, 
переконання (Погрібна, 2009). Розробка концептуального рівня моделі управління наступністю дошкільної та початкової шкільної освіти розглядається як спроба представити її по-іншому, знайти нестандартне рішення.

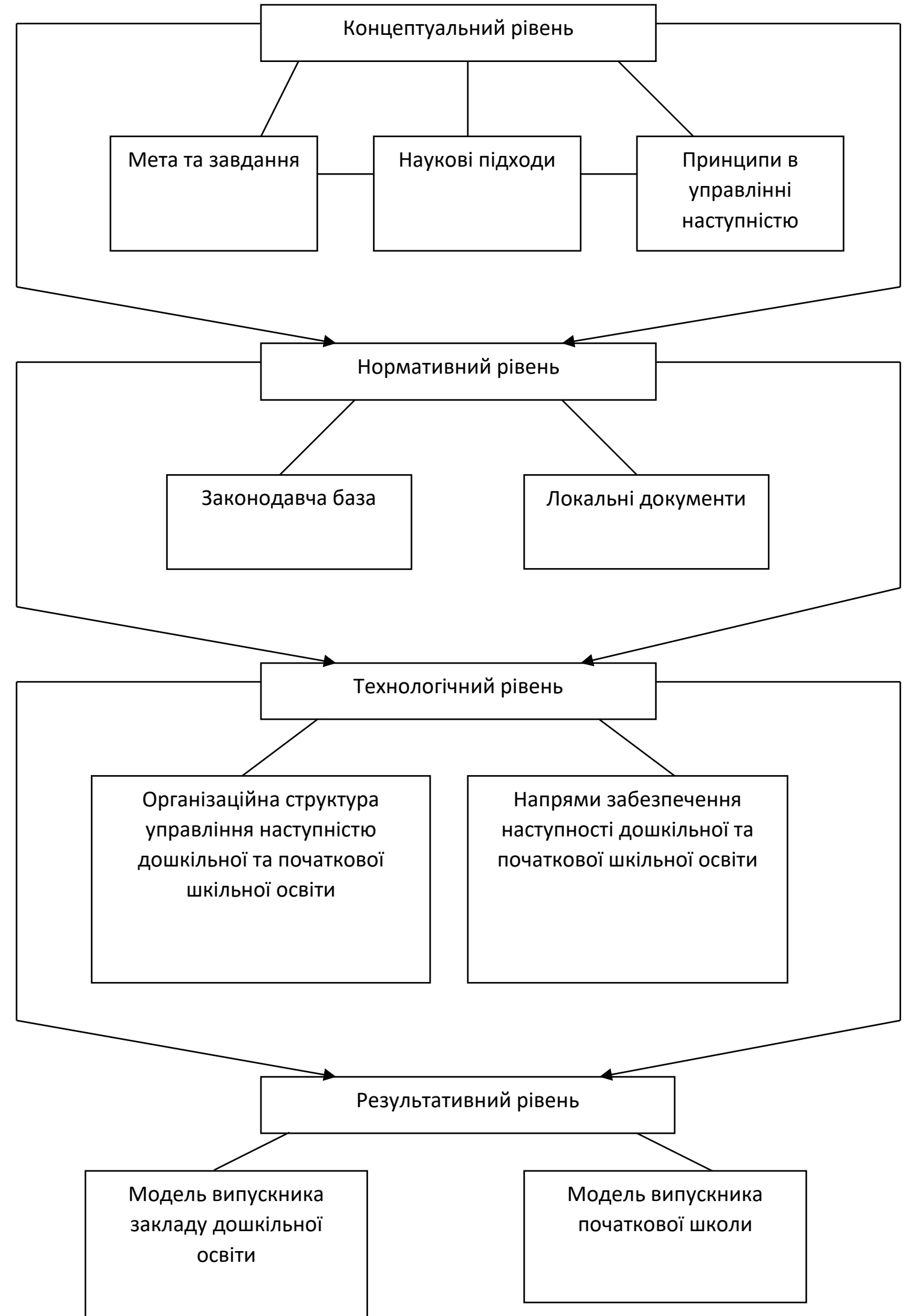

Рисунок 1 Модель управління наступністю дошкільної та початкової шкільної освіти 
Ми вважаємо, що універсальної концепції навчання, придатної для різних освітніх установ, бути не може. Кожна освітня установа, співтовариство вихованців-батьків-вихователів, учнів-батьків-учителів, усвідомлено проектуючи свій власний, несхожий на інші освітній процес, мислить і діє в динамічно мінливому концептуальному полі.

Зміст концептуального рівня розкриває мету, завдання управління наступністю дошкільної та початкової шкільної освіти закладу загальної середньої освіти, наукові підходи і принципи до управління навчальним закладом.

В основу змісту концептуального рівня покладено сучасні наукові підходи до управління наступністю дошкільної та початкової шкільної освіти у закладі загальної середньої освіти, серед яких пріоритетне місце посідають: діяльнісний, системний, цілісний, адаптивний, гуманістичний, стратегічний.

В управлінні наступністю дошкільної та початкової шкільної освіти виділяють наступні принципи діяльності керівника (Конаржевський, 1986, с. 83): наступності, варіативності, персоніфікації, постійного професійного зростання, інформованості, гнучкості й динамізму.

Основна мета нормативного рівня моделі управління наступністю дошкільної та початкової шкільної освіти полягає у визначенні законодавчої бази та розробки локальних документів щодо управління наступністю.

Законодавча база управління дошкільної та початкової шкільної освіти складається 3: «Закону України про освіту», «Закону України про загальну середню освіту», «Закону України про дошкільну освіту», Державного стандарту початкової загальної освіти, Базового компонента дошкільної освіти, Концепції нової української школи тощо.

Ключовим аспектом організації управління навчальним закладом $\epsilon$ створення структури, елементи якої функціонують і розвиваються як єдине ціле. При розподілі завдань і функцій, прав і обов'язків працівників відбувається рух інформації і приймаються управлінські рішення. Діяльність навчального закладу регламентується різними документами. Зовнішня діяльність (взаємодія з державними органами, третіми особами) регламентується нормативними законодавчими актами, чинними на тій території, на якій заклад освіти здійснює свою діяльність. Внутрішня діяльність закладу освіти регламентується внутрішніми (локальними) документами.

Головною умовою забезпечення наступності у вихованні та навчанні $є$ спрямованість педагогічного процесу дошкільного закладу освіти і початкової школи на всебічний розвиток особистості дитини.

Технологічний рівень моделі управління наступністю дошкільної та початкової шкільної освіти представлений організаційною структурою управління наступністю дошкільної та початкової шкільної освіти та напрямами забезпечення наступності дошкільної та початкової шкільної освіти.

Організаційна структура управління наступністю дошкільної та початкової шкільної освіти представлена на рисунку 2, на якому зображені суб'єкти діяльності та зв'язки між ними.

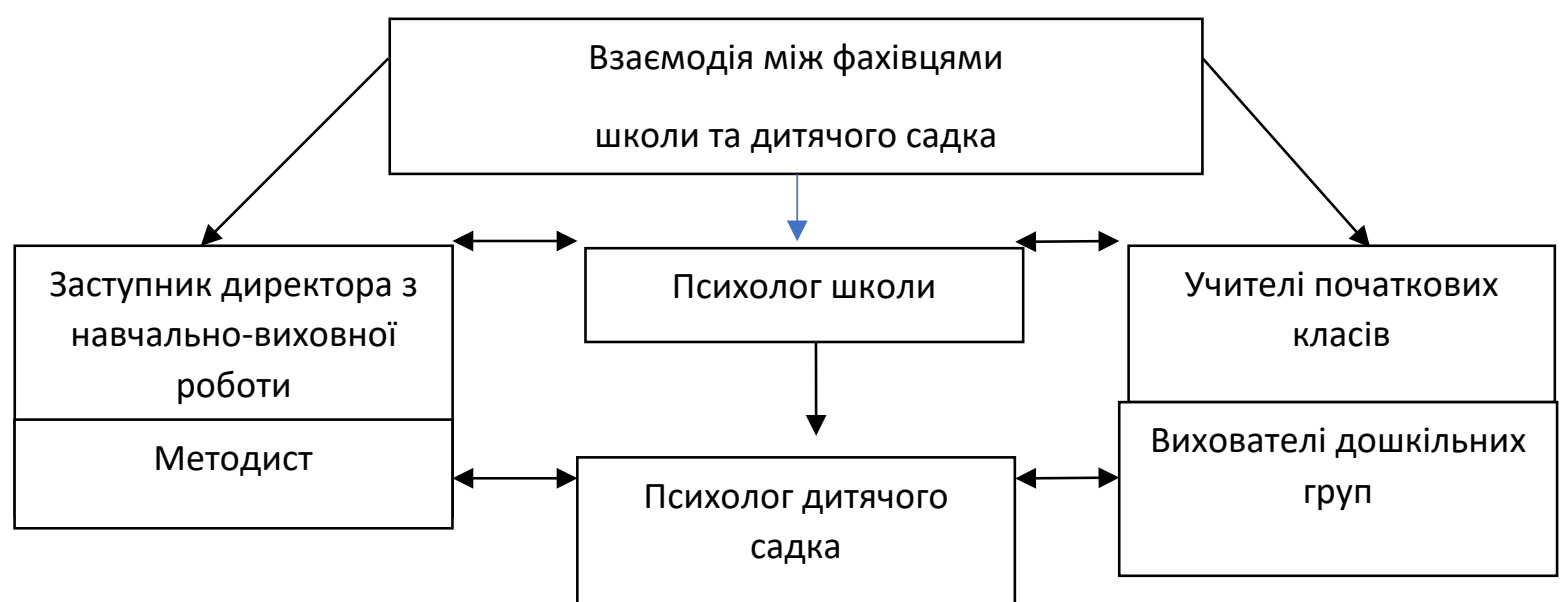

Рисунок 2 Організаційна структура управління наступністю дошкільної та початкової шкільної освіти

Щоб забезпечити наступність між дошкільною і початковою освітою, важливо впровадити єдину і динамічну систему конструктивних дій, спрямованих на розвиток, навчання і виховання старших дошкільників і початківцівшколярів, застосування яких буде спільним і для управлінців, і педагогів, і батьків.

Задля ефективного функціонування такої системи, в першу чергу, необхідно налагодити взаємодію між закладами освіти (або відповідними структурними підрозділами закладу освіти) на основі угоди про співпрацю. В угоді про співпрацю визначають: мету співпраці, права та обов'язки кожного закладу освіти. Угоду укладають директори закладів освіти у червні кожного року. Схема взаємодії закладів має визначати: порядок дій, які будуть корегуватися 3 урахуванням фактичних умов; перспективи функціонування закладів освіти (або відповідних структурних підрозділів закладу освіти).

Орієнтовний перелік дій для створення єдиної системи взаємодії закладів освіти:

1) проведення внутрішнього дослідження якості освіти - послідовних систематичних заходів у межах річного плану роботи закладів задля:

- виявлення та відстежування ознак розвитку освіти;

- встановлення відповідності між фактичними результатами освітньої діяльності та заявленими цілями;

- оцінювання ступенів, напрямів і причин відхилень від заявлених цілей;

2) обговорення проблемних питань організації освітнього процесу і виокремлення завдань, які потрібно виконати на конкретному етапі роботи; 
3) розроблення плану та проведення спільних заходів згідно з окресленими завданнями за участі адміністрацій і методичних служб закладів освіти, батьків дітей старшого дошкільного віку.

Щоб забезпечити наступність у роботі закладу дошкільної освіти і школи, необхідно організовувати методичну роботу за двома напрямами: інформаційно-просвітницьким практичним.

Інформаційно-просвітницький аспект співпраці між закладами. Важливим елементом наступності дошкільної і початкової освіти є обмін досвідом між вихователями та вчителями початкової школи щодо:

- використання різноманітних форм організації діяльності дітей, ігрових прийомів і методів;

- систем роботи з розвитку мовлення;

- поетапної соціалізації дитини, формування ії пізнавальних процесів.

Для обміну досвідом плануйте індивідуальні та інтерактивні (групові, колективні, колективно-групові) форми методичної роботи. Зокрема, застосовуйте такі форми методичної роботи:

- взаємне почергове відвідування вихователями і вчителями відкритих занять/уроків (або інших форм організації освітньої роботи);

- проведення анкетування педпрацівників з питань забезпечення гармонічного розвитку особистості дитини 3 метою встановлення напрямків для підвищення їх майстерності;

- підготовка і проведення спільних семінарів-практикумів, конференцій, консультацій, педагогічних рад, засідань «круглих столів», тематичних виставок тощо;

- організація спільних методичних об’єднань, творчих груп педпрацівників закладів дошкільної освіти і початкової школи;

- залучення вихователів та вчителів до участі у проведенні спільних педагогічних проектів, розробленні методичних рекомендацій і порад;

- взаємний обмін педагогічним досвідом щодо практичних питань реалізації наступності між дошкільною і початковою ланками освіти;

- сприяння і надання допомоги у самоосвіті педагогів, систематичному підвищенні їх фахової майстерності.

Інформаційно-просвітницький аспект взаємодії закладів дошкільної та початкової освіти необхідно спрямовувати і на педагогів, і на батьків. У роботі з батьками передбачати:

- анкетування щодо питань індивідуального розвитку особистості дітей, рівня досягнення ними дошкільної зрілості з метою надання консультативної допомоги;

- ознайомлювальну роботу щодо психологічних закономірностей розвитку дитини старшого дошкільного та молодшого шкільного віку;

- Дні відкритих дверей у закладах загальної середньої освіти;

- «педагогічні вітальні» у школі з питань створення у закладі психологічно комфортної обстановки для сприйняття дитиною нової соціальної ролі школяра;

- батьківські клуби;

- інтернет-консультації, вебінари або форуми для батьків тощо.

Практичний аспект співпраці між закладами. Необхідною умовою успішного вирішення завдань наступності $€$ встановлення зв'язку та творчої співпраці між закладом дошкільної освіти і початковою школою на рівні заходів 3 дітьми.

Напрямки реалізації практичного аспекту співробітництва між освітніми закладами:

- попереднє знайомство педагогів початкової школи зі своїми майбутніми учнями;

- відвідування вихователями відкритих уроків, позакласних заходів своїх колишніх вихованців-першокласників 3 метою спостереження за їх розвитком;

- проведення ознайомлювальних екскурсій для дітей;

- організація спільних конкурсів, тематичних виставок дитячих робіт, вернісажів тощо;

- проведення спільних митецьких заходів у закладах дошкільної та загальної середньої освіти (відвідування музеїв, театралізованих вистав тощо);

- спільна участь старших дошкільнят і школярів у проектній діяльності тощо.

Задля наступності дошкільної і початкової освіти обов'язково має бути узгоджена діяльність психологічних служб закладів. Взаємодія закладу дошкільної освіти і початкової школи у питанні роботи соціально-психологічних служб включає:

- здійснення спільного психолого-педагогічного контролю за процесом розвитку дітей;

- дослідження рівня розвитку основних рис особистості дітей старшого дошкільного віку як передумови успішного навчання у початковій школі;

- аналіз умов вдалої адаптації першокласників до шкільного життя;

- використання розвивально-корекційних прийомів у роботі з дітьми, які потребують індивідуального підходу;

- проведення спільних методичних заходів.

Зміст конкретних заходів (зокрема, теми і питання засідань круглих столів, семінарів-практикумів, педрад, методоб’єднань тощо) зазначають у річних планах роботи закладу дошкільної освіти та закладу загальної середньої освіти.

Результативний рівень запропонованої моделі полягає у кінцевому результаті - створенні моделі випускника дошкільного закладу освіти та моделі випускника початкової школи. Результат - це втілена мета, яка більше чи менше збігається з відповідним взірцем.

Під моделлю випускника розуміється передбачуваний результат спільної діяльності дитячого садка і сім'ї, що характеризує їх уявлення про найбільш важливі якості особистості дитини, якими має володіти випускник дошкільного закладу освіти. 
Модель випускника має велике теоретичне і практичне значення:

- по-перше, вона виконує інтегруючу роль по відношенню до інших складових образів дошкільної установи;

- по-друге, є основою для розробки цільових орієнтирів освітнього процесу, що дозволяють максимально враховувати особливості навколишнього середовища, специфіки установи, своєрідність педагогічного колективу;

- по-трете, модель випускника виступає як основний критерій ефективності освіти, завдяки якому можна співвіднести отримані результати з думкою педагогів, медичних працівників дошкільного закладу освіти та батьків про бажані результати.

Характерна риса випускника дошкільного закладу освіти - стійке позитивне ставлення до себе, впевненість у своїх силах, відкритість зовнішньому світу. Це знаходить прояв у грі, так як розвиненість ігрової діяльності є показником готовності до навчального процесу.

Модель випускника дошкільного закладу освіти має такі складові:

- психологічна та соціальна готовність до школи;

- розвиток психофізіологічних функцій;

- розвиток пізнавальної діяльності;

-фізичний розвиток.

Початкова школа, спираючись на набуття дошкільного дитинства, має забезпечити подальше становлення особистості дитини, iї інтелектуальний, соціальний, фізичний розвиток. У початкових класах діти укріплюють: ціннісне ставлення до рідного краю, держави, української культури здатність до критичного мислення та творчого самовираження бережливе ставлення до здоров'я тощо.

Забезпечуючи наступність та перспективність у роботі закладу дошкільної освіти і початкової школи, можливо створити умови для всебічного гармонійного розвитку ініціативної, компетентної та самодостатньої особистості на перших суміжних ланках системи безперервної освіти.

Реалізація принципів перспективності й наступності у закладах дошкільної та початкової освіти полягає у забезпеченні єдності, взаємозалежності та узгодженості мети, змісту, форм і методів організації освітнього процесу:

- учителі початкових класів мають бути добре обізнаними з освітніми програмами, методами і прийомами розвитку, навчання, виховання дітей старшого дошкільного віку, застосовуваними в закладах дошкільної освіти;

- вихователі старших груп мають бути ознайомлені з освітніми програмами і технологіями навчання початкової школи.

Це необхідно, щоб уникнути ситуацій форсування або, навпаки, штучного уповільнення природного темпу розвитку дітей. Крім того, змістовий і технологічний складові освітнього процесу в закладі дошкільної освіти та початковій школі доцільно узгоджувати з урахуванням вікових та індивідуальних особливостей дітей.

Висновки. Отже, дотримуватися принципу наступності дошкільної і початкової освіти шляхом узгодженості підходів до організації життєдіяльності дитини важливо незалежно від соціально-педагогічних умов здобуття нею освіти - в закладі дошкільної освіти, початковій школі, в Центрі розвитку дітей чи просто в умовах сімейного (домашнього) виховання. Зберігаючи наступність, заклад дошкільної освіти і школа мають провадити освітню діяльність спільно і системно - всім педагогічним колективом. Лише об'єднавши зусилля педколективів закладів дошкільної і початкової ланок шкільної освіти, а також отримавши підтримку батьківської громади можливо забезпечити психологічно виважений і успішний для дитини перехід з попереднього рівня освіти на наступний.

\section{Список використаних джерел}

Інструктивно-методичні рекомендації щуодо забезпечення наступності дошкільної та початкової освіти (лист МОН України від 19.04.2018 № 1/9-249). Доступно: https://www.pedrada.com.ua/article/2345-zabezpechennyanastupnost-zdo-ta-nush [Дата звернення 22 листопада 2020].

Кожевников, В. М., 2007. Наступність етапів освіти // Наступність між початковою та основною ланками в контексті переходу школи на 12-річний термін навчання : матеріали електронної Всеукраӥн. наук.-практ. конф., 19 червня-19 жовтня 2006 р. Т. 1. Донецьк : Донбас, с. 21-23.

Конаржевский, Ю. А., 1986. Педагогический анализ учебно-воспитательного процесса и управление школой. Москва: Педагогика, $144 \mathrm{c}$.

Погрібна Н., 2009. Управляти школою по-новому... Київ: Шкільний світ, 120 с.

\section{References}

Instruktyvno-metodychni rekomendatsii shchodo zabezpechennia nastupnosti doshkilnoi ta pochatkovoi osvity (lyst MON Ukrainy vid 19.04.2018 № 1/9-249). Dostupno: https://www.pedrada.com.ua/article/2345-zabezpechennyanastupnost-zdo-ta-nush [Data zvernennia 22 lystopada 2020].

Kozhevnykov, V. M., 2007. Nastupnist etapiv osvity // Nastupnist mizh pochatkovoiu ta osnovnoiu lankamy v konteksti perekhodu shkoly na 12-richnyi termin navchannia : materialy elektronnoi Vseukrain. nauk.-prakt. konf., 19 chervnia19 zhovtnia 2006 r. T. 1. Donetsk : Donbas, s. 21-23.

Konarzhevskij, Yu. A., 1986. Pedagogicheskij analiz uchebno-vospitatelnogo processa i upravlenie shkoloj. Moskva: Pedagogika, $144 \mathrm{~s}$.

Pohribna N., 2009. Upravliaty shkoloiu po-novomu... Kyiv: Shkilnyi svit, 120 s. 


\section{BERETSKA S.}

Vasyl’ Stus Donetsk National University, Vinnytsia, Ukraine

\section{MODEL OF MANAGEMENT OF CONTINUITY OF PRESCHOOL AND PRIMARY SCHOOL EDUCATION}

The article is devoted to substantiation of the model of continuity management of preschool and primary school education. The model of managing the continuity of preschool and primary school education is considered as a tool for constructing future situations, finding alternatives in the development of educational institutions and ensuring its competitiveness. The content of the model is clarified through conceptual, normative, technological and performance levels that are interdependent and interrelated.

The content of the conceptual level reveals the purpose, objectives of continuity management of preschool and primary school education of general secondary education, scientific approaches and principles to the management of the educational institution. The main purpose of the normative level of the model of continuity management of preschool and primary school education is to determine the legal framework and develop local documents on continuity management. The technological level of the model of continuity management of preschool and primary school education is represented by the organizational structure of continuity management of preschool and primary school education and areas of continuity of preschool and primary school education. The effective level of the model is the end result - the creation of a model of a preschool graduate and a model of a primary school graduate. The result is an embodied goal that more or less coincides with the corresponding pattern.

It is emphasized that in the process of modeling and direct construction of the model the following principles were used: multivector influence on the system, system-structural analysis, level approach, sequence and logic of the main stages of search, specificity, expediency of selected methods, integrity and completeness of processes. It is noted that maintaining continuity, the preschool institution and the school should conduct educational activities jointly and systematically - the entire teaching staff. It is emphasized that only by uniting the efforts of pedagogical staff of preschool and primary schools, as well as with the support of the parent community, it is possible to ensure a psychologically balanced and successful transition for the child from the previous level of education to the next.

Keywords: continuity, management, model, continuity, preschool education, primary school education.

Стаття надійшла до редакції 12 жовтня 2020 р.

УДК 378.091.39:004

https://doi.org/10.33989/2075-146x.2020.26.227421

LUDMILA BLAZHKO

ORCID 0000-0002-0472-276X

INNA RASSOKHA

ORCID 0000-0001-7681-5124

SERGIY RENDIUK

ORCID 0000-0003-1593-7632

National University «Yuri Kondratyuk Poltava Polytechnic», Poltava, Ukraine

\section{USE OF MOBILE APPLICATIONS IN THE LEARNING PROCESS}

Nowadays the interest in integrating mobile applications into the learning process is increasing rapidly, so we need such teaching methods that will facilitate and accelerate the transmission of knowledge to students, intensify the process of learning, teach them techniques for independent work with material, increase productivity of learning and teacher's work. Such teaching methods can be implemented through the use of mobile information technology in education.

The article considers the concept of "mobile learning", analyzes the features and directions of its use in modern education. It is noted that the use of mobile electronic devices and applications in higher mathematics allows you to check quickly the solution, to draw the chart in a few minutes as well as to apply them to distance learning, which greatly facilitates and accelerates knowledge, increases students' productivity and independent work. It is also noted that despite the widespread use and availability of mobile phones among students, mobile learning is not widespread in native universities. The didactic principles to which mobile applications should correspond are defined, and also the attention to the basic advantages and disadvantages of the use of mobile applications in learning process of higher mathematics is paid.

Keywords: mobile applications, mobile learning, mobile devices, mobile technologies, higher mathematics, technical universities

Topicality. The current state of teaching higher mathematics to students of technical specialties is characterized by contradictions between insufficient level of basic mathematical preparation of students and a complex logical structure and a 